\title{
Spiders (Arachnida: Araneae) of the vegetation layer of the Mkambati Nature Reserve, Eastern Cape, South Africa
}

\author{
Authors: \\ Anna S. Dippenaar- \\ Schoeman ${ }^{1,2}$ \\ Michelle Hamer ${ }^{3,4}$ \\ Charles R. Haddad ${ }^{5}$ \\ Affiliations: \\ ${ }^{1}$ ARC-Plant Protection \\ Research Institute, \\ Queenswood, South Africa \\ ${ }^{2}$ Department of Entomology \\ and Zoology, University of \\ Pretoria, South Africa \\ ${ }^{3}$ South African Biosystematics \\ Institute, Pretoria, \\ South Africa \\ ${ }^{4}$ School of Biological and \\ Conservation Science, \\ University of KwaZulu-Natal, \\ South Africa \\ ${ }^{5}$ Department of Zoology and \\ Entomology, University of the \\ Free State, South Africa \\ Correspondence to: \\ Charles Haddad \\ Email: \\ haddadcr@ufs.ac.za \\ Postal address: \\ P.O. Box 339, Bloemfontein \\ 9300 , South Africa \\ Dates: \\ Received: 27 May 2011 \\ Accepted: 07 Sept. 2011 \\ Published: 11 Nov. 2011 \\ How to cite this article: \\ Dippenaar-Schoeman, A.S., \\ Hamer, M. \& Haddad, C.R., \\ 2011, 'Spiders (Arachnida: \\ Araneae) of the vegetation \\ layer of the Mkambati Nature \\ Reserve, Eastern Cape, South \\ Africa', Koedoe 53(1), Art. \\ \#1058, 10 pages. http:// \\ dx.doi.org/10.4102/koedoe. \\ v53i1.1058
}

(C) 2011. The Authors. Licensee: AOSIS OpenJournals. This work is licensed under the Creative Commons Attribution License.
The Pondoland region of the Eastern Cape province, South Africa is very poorly studied with regard to invertebrate diversity, particularly in the case of arachnids. Accordingly, and in view of proposed infrastructural and mining developments in this ecologically sensitive area of high plant endemism, baseline data are provided on spiders (Araneae) of the vegetation layer (i.e. excluding the ground-dwelling fauna) of the Mkambati Nature Reserve (MNR). Spiders were collected at 26 sites (six forest and 20 grassland sites) in the MNR over an eight-day period, using sweep sampling and active searching of flowers in grassland and tree beating in forests, as part of a broader biodiversity survey. Additional specimens were collected with Malaise and pan traps. A total of 1275 specimens were sampled, representing 132 species (6.6\% of the total number recorded in South Africa) in 103 genera and 29 families. Theridiidae and Araneidae were the most diverse spider families in the reserve, represented by 22 species each $(16.7 \%$ of the total), followed by Thomisidae with 19 species $(14.4 \%)$ and Salticidae with 18 species (13.6\%). Grassland and forest had distinct spider faunas, with only $24.2 \%$ of species being recorded from both biomes. The average number of species sampled per site in grassland and forest was 26 species for both habitats, although values for the two biomes are not directly comparable because different sampling methods were used. All 132 species are new records for the reserve, of which 20 were new records for the Eastern Cape and at least eight spider species may be new to science. The spider diversity captured despite temporal and methodological limits indicates that many additional species are likely to occur in the reserve.

Conservation implications: If the MNR is not adequately conserved at least five new species, which may be confined to the area, would be at high risk of extinction and 15 other species endemic to the Pondoland and KwaZulu-Natal region would have their risk of extinction increased.

\section{Introduction}

The conservation of biodiversity is critical to the well-being of humans owing to its provision of ecosystem services (Millennium Ecosystem Assessment 2005). In addition, biodiversity, especially where unique and rich, can also contribute to economic development through ecotourism (Kepe 2001). However, to identify key areas for conservation and ecotourism and to monitor the effects of protection, management and/or threats, biodiversity inventories are essential and are considered by conservationists as being good investments (Balmford \& Gaston 1999; Rohr, Mahan \& Kim 2007; Ward \& Larivière 2004).

Invertebrates have become recognised as an important component of biodiversity. They are important in all ecosystems with regard to species richness (an estimated $95 \%$ of all species are invertebrates), abundance and biomass, and they play vital roles in ecosystem functioning (see, for example, Black, Shepard \& Allen 2001; Janzen 1987; Luck, Daily \& Ehrlich 2003). Spiders (Araneae) are one of the largest orders of terrestrial invertebrates, with more than 40000 described species (Platnick 2010), and are predacious in all of their life stages. They therefore play an important role in terrestrial food webs as arthropod population regulators, whilst also providing food for other predators (Gruner 2004; Schmitz 2003).

The South African National Survey of Arachnida was initiated in 1997 to document the diversity and distribution of arachnids in the country (Dippenaar-Schoeman \& Craemer 2000). Surveys have been carried out across many of the provinces, biomes, agro-ecosystems and protected areas of South Africa (Dippenaar et al. 2008; Dippenaar-Schoeman 2006; Dippenaar-Schoeman \& Leroy 2003; Dippenaar-Schoeman et al. 1999, 2005; Dippenaar-Schoeman, Van den Berg \& Prendini 2009; Foord et al. 2008; Haddad \& Dippenaar-Schoeman 2009; Haddad, Dippenaar-Schoeman \& Wesolowska 2006), thereby generating the data that are critical for a conservation assessment of species and for understanding habitats and vegetation types of conservation concern for arachnids. 
Whilst the Pondoland region of the Eastern Cape, South Africa is recognised as a centre of high plant diversity and endemism (Van Wyk \& Smith 2001), the spider fauna of the region is still poorly known and no structured surveys or sampling using standard methods and a consistent number of samples across sites (i.e. quantified surveys) have previously been carried out in the region. The environmental impact assessment report for a proposed national toll road through the region acknowledged the poor state of knowledge regarding invertebrates of the area (Branch 2002). Quantified surveys are critical for comparisons of areas and for providing future baseline data for monitoring (Rohr et al. 2007).

The Mkambati Nature Reserve (MNR) was selected for the survey of invertebrates in 2008 because of possible tourism development in the reserve (Kepe 2001), the proposed construction of a toll road adjacent to the reserve (Branch 2002; Farrington \& Davies 2004), the threat of controversial open cast dune mining in the region and the lack of invertebrate data to support planning and decision-making. The survey targeted a range of invertebrates, including spiders. The objectives of this particular paper are (1) to provide an annotated species list of spiders sampled from the vegetation layer at the MNR, (2) to provide an analysis of the spider faunal composition with regard to taxonomic breakdown and guilds, and (3) to assess the fauna with regard to species abundance or rarity, levels of endemism and the habitats used by species.

Spider guilds can be broadly divided into ground dwellers, plant dwellers and web dwellers. Sampling in the MNR focused mainly on two of these guilds, namely plant dwellers and web dwellers. It should be noted that this survey is still incomplete because few ground dwellers, usually sampled with pitfall traps and litter sampling methods, were collected. Community and detailed habitat analyses will be presented as part of a broader invertebrate publication (Hamer et al. in prep.).

\section{Materials and methods}

\section{Study area and period}

The MNR $\left(31^{\circ} 15^{\prime} \mathrm{S}, 2^{\circ} 56^{\prime} \mathrm{E}\right)$ is situated in north-eastern Pondoland, $30 \mathrm{~km}$ south of Port Edward in the Eastern Cape, South Africa (Figure 1). This coastal reserve is 7720 ha in size, and comprises mainly open grasslands with patches of coastal, dune and swamp forest (Figure 2). The climate is subtropical, with summer rainfall (annual average $=1200 \mathrm{~mm}$ ).

We surveyed the MNR between 24 January and 3 February 2008 and sampled a total of 26 sites, which included six forest (coastal forest, swamp forest and dune forest) and 20 grassland sites. The sample sites covered localities from the coast at 16 m.a.s.l., those near wetlands, on rocky hills or slopes, and inland sites at 311 m.a.s.l. (Figure 2; Table 1). Sampling was undertaken primarily by seven Earthwatch Institute volunteers, who had no previous biodiversity survey experience, and seven experienced technicians or scientists under the supervision of the second author. The volunteers attended an introductory presentation on the project and sampling methods and were then trained on site. They received close guidance from the experienced project staff during the actual sampling. Previous studies have shown that volunteers are capable of producing similar diversity results when compared with experienced researchers (Lovell

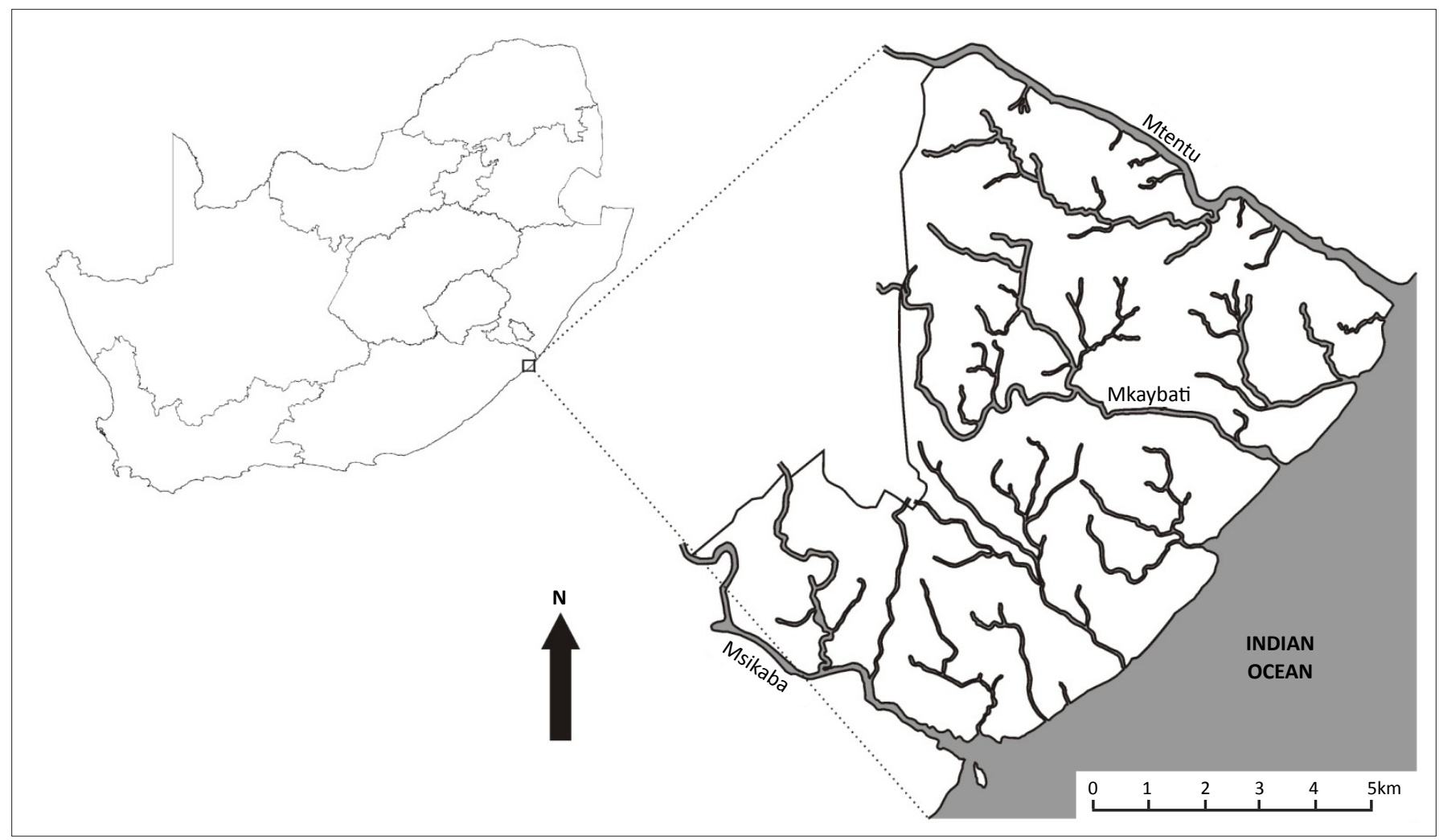

FIGURE 1: Location and extent of the Mkambati Nature Reserve, South Africa and its main river systems. 

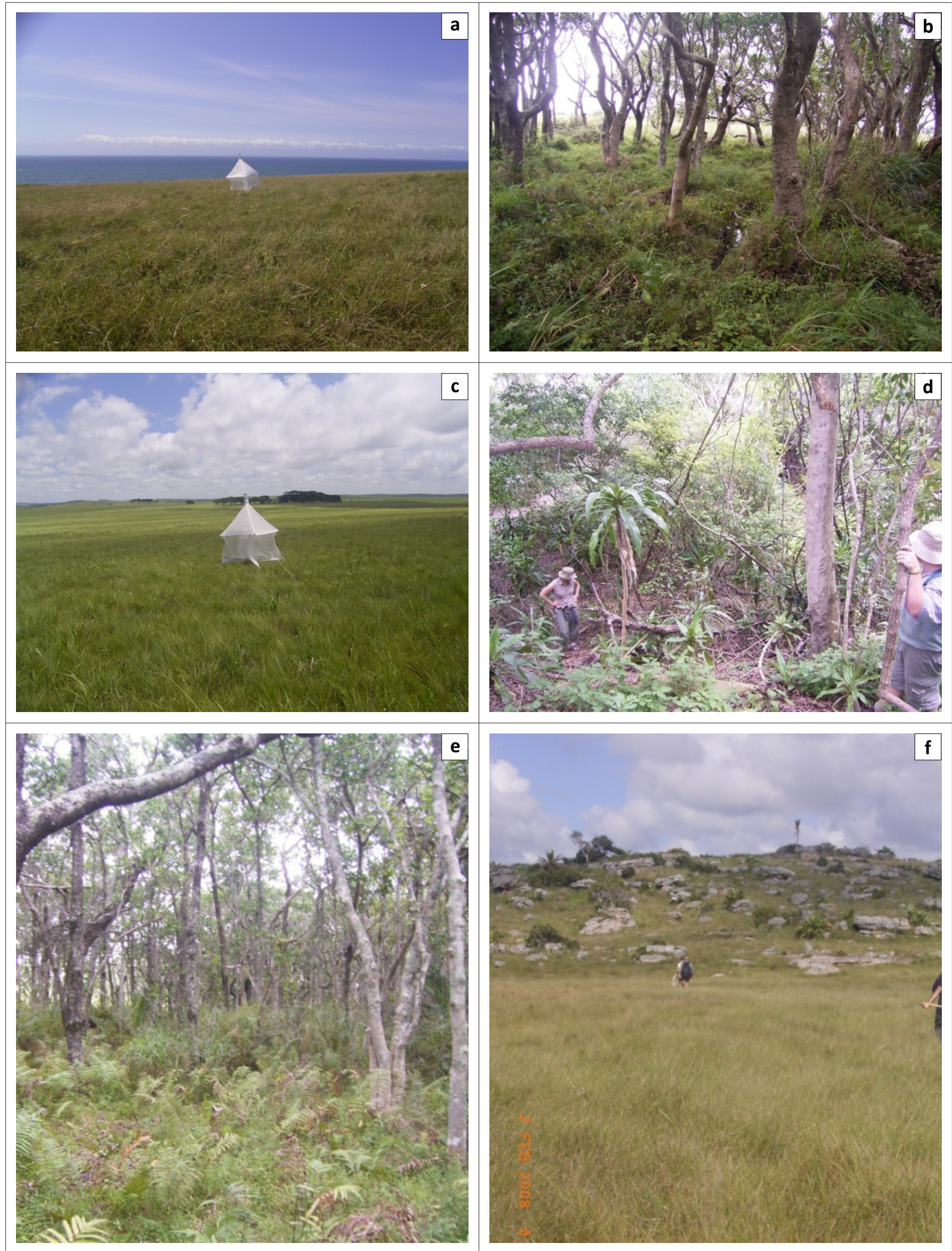

FIGURE 2: Habitats sampled at the Mkambati Nature Reserve: a) Site 1 (grassland), b) Site 11 (forest), c) Site 19 (grassland), d) Site 12 (forest), e) Site 15 (forest), f) Site 10 (grassland), g) Site 25 (grassland) and h) Site 26 (forest).

Figure 2 continues on the next page $\rightarrow$ 

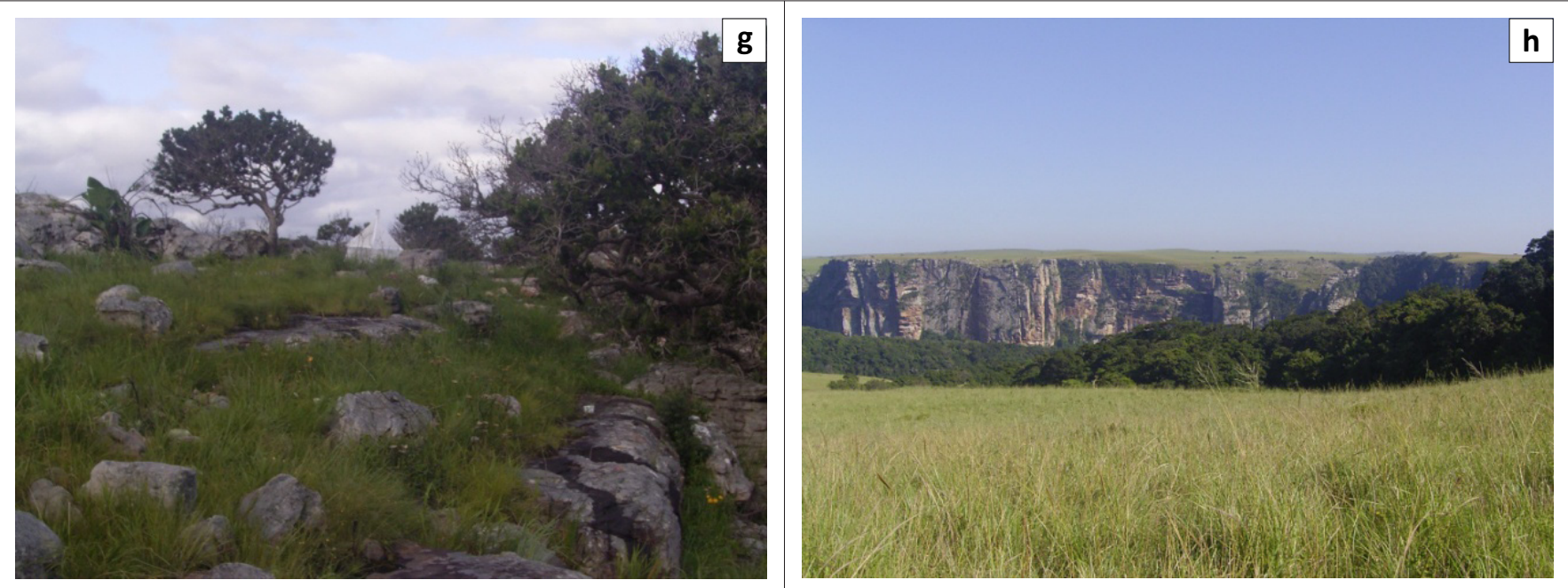

FIGURE 2 (Continues...): Habitats sampled at the Mkambati Nature Reserve: a) Site 1 (grassland), b) Site 11 (forest), c) Site 19 (grassland), d) Site 12 (forest), e) Site 15 (forest), f) Site 10 (grassland), g) Site 25 (grassland) and h) Site 26 (forest).

et al. 2009) and their contribution to the current biodiversity survey was thus considered adequate to get a representation of the spider fauna of the area. Considering the size of the survey team, the sampling effort was 112 'person-days'.

\section{Sampling methods}

Details of sampling methods used at each site are provided in Table 1.

\section{Grassland sampling}

Grassland sampling included setting one Malaise trap and five each of yellow, blue and white pan traps, which were collected after five days, at each site (approximately 1 ha). Six sweep samples, each comprising 40 sweeps (approximately $1 \mathrm{~m}$ apart) with a 50-cm diameter net, were taken from selected sites. Active searching for spiders on 40 flowers was carried out at 10 of the grassland sites. This sampling involved examination of the upper and lower surfaces of each flower and the capture of any spiders observed using a vial. There was no time limit set for examination of flowers.

\section{Forest sampling}

Ten trees in each forest site were beaten to sample selected invertebrates, including spiders. For this method each tree was struck 10 times with a beating stick and a white tray $(80 \mathrm{~cm} \times 80 \mathrm{~cm})$ was held underneath to collect specimens that dropped from the tree. An aspirator was used to capture small specimens.

Specimens were preserved in $80 \%$ ethanol and later sorted in the laboratory according to sample and morphospecies. The first and third authors subsequently identified the specimens to species level, where possible. Voucher specimens are housed at the National Collection of Arachnida of the ARCPlant Protection Research Institute in Pretoria, South Africa.

\section{Results}

\section{Species inventory and faunal composition}

A total of 1275 specimens were sampled, representing 132 species $(6.6 \%$ of the total recorded in South Africa) in
103 genera (95 identified) and 29 families (Appendix and Table 2). Theridiidae and Araneidae were the most diverse spider families sampled in the reserve, represented by 22 species each (16.7\% of the total number of species), followed by Thomisidae (19 species; $14.4 \%$ ) and Salticidae (18 species; 13.6\%). Neoscona blondeli (Simon, 1885) (Araneidae) represented $13.0 \%$ of the spider specimens sampled, followed by Heliophanus proszynskii Wesołowska, 2003 (Salticidae) at $7.8 \%$ (Table 2$)$. Of the sampled species, 38 (28.8\%) could not be identified beyond genus level and a further eight species $(6.1 \%)$ could not be assigned to a genus. An equal number (66) of web-dwelling and wandering species were sampled (Appendix).

The highest number of individuals ( $n=635,49.8 \%$ ) was sampled using sweep-netting, followed by tree beating, with which 342 individuals $(26.8 \%)$ were sampled. Pantraps sampled 206 individuals (16.2\%) and other methods provided 92 specimens $(7.2 \%)$.

\section{Species prevalence, rarity, endemism and habitats}

Of the total number of species sampled, 35 (26.5\%) occurred only in forest and $65(49.2 \%)$ were confined to grassland. Only 32 species $(24.2 \%)$ occurred in both habitat types. At one site 45 species $(34.1 \%)$ were recorded, whilst 40 species $(30.3 \%)$ were represented by only a single individual (singletons).

No species was sampled at all the sites and only seven species (5\%) were recorded from more than $50 \%$ of the sampled sites (both forest and grassland). The most regularly collected species across sites were N. blondeli and Copa flavoplumosa Simon, 1885 (Corinnidae), which were sampled at 20 sites, Theridion sp. 1 (Theridiidae) and Clubiona sp. 3 (Clubionidae), which were collected from 17 sites, and H. proszynskii, which was collected at 16 sites. These were also the most abundant species.

All 132 species are new records for the reserve and eight species (6.1\% of the total) may be new to science. These species belong to the genera Chresiona Simon, 1903 (Amaurobiidae), 
TABLE 1: Details of sites and sampling methods used during the survey at Mkambati Nature Reserve (January-February 2008).

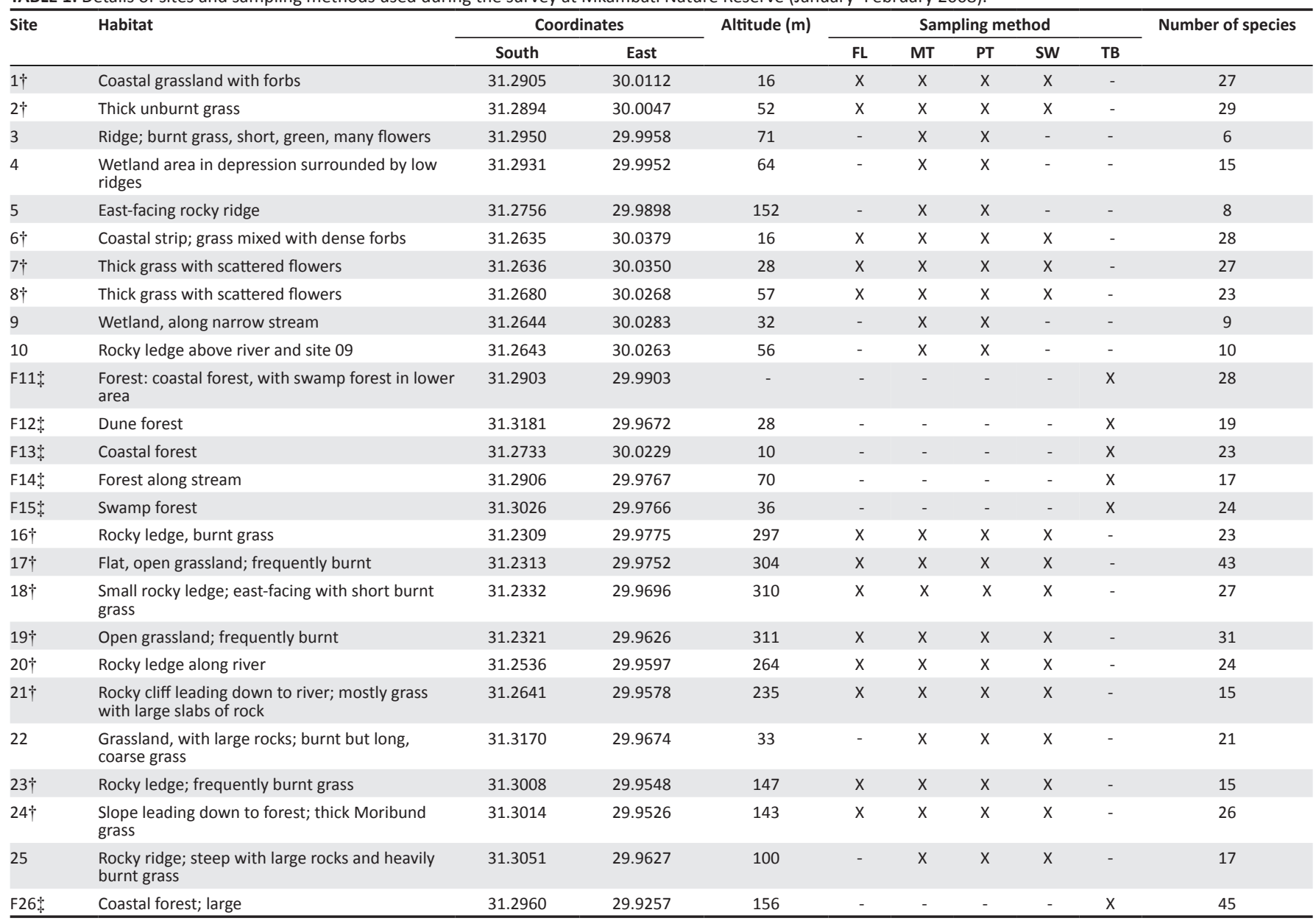

$\mathrm{FL}$, flower sampling; MT, Malaise traps; PT, pan traps; SW, sweep-netting; TB, tree beating.

$\dagger$, Grassland sites at which the full suite of sampling methods targeting spiders was carried out.

$*$ Forest sites at which the full suite of sampling methods targeting spiders was carried out.

Araniella Chamberlin \& Ivie, 1942, Cyrtophora Simon, 1864, Hypsosinga Ausserer, 1871 and Poltys C.L. Koch, 1843 (Araneidae), Typhistes Simon, 1894 (Linyphiidae), Cheiramiona Lotz \& Dippenaar-Schoeman, 1999 (Miturgidae) and Tibitanus Simon, 1907 (Philodromidae). Five of these species may be confined to the reserve or the Pondoland region as they have not been collected previously in surveys of other areas. A further 15 species are known only from the Eastern Cape and one other province, and another 11 species are South African endemics (Appendix).

The number of species recorded at a grassland site, where the full suite of sampling methods was used, ranged between 15 and 43 , with an average number of 26 species per site. The range for forests was $17-45$ species, also with an average of 26 species per forest. Site 17, a flat, open inland area with frequently burnt grass, had the highest measured richness for grassland. Site F26, a large forest in an inland gorge (known as the Superbowl), had the highest measured forest richness (Table 1).

\section{Discussion}

It should be noted that this survey produced a preliminary species list and that additional methods, sites and survey timing will produce many more species. Other spider surveys have shown that species numbers increased with increased sampling effort (e.g. Cardoso et al. 2008, 2009; Muelelwa et al. 2010). However, given the large efforts and costs required to sample, sort and identify invertebrates such as spiders, completing the inventory is unlikely to occur in the short term. Given the urgency for biodiversity data, especially with regard to invertebrates, even incomplete data sets have relevance. The identification of at least eight possibly new species over eight days of sampling illustrates just how poorly known the fauna of Pondoland is.

The $30 \%$ of singletons sampled at the MNR is close to the average of $32 \%$ calculated by Coddington et al. (2009) from 71 studies. The authors suggested that very high percentages of singletons indicate undersampling, but they also recognised that undersampling is virtually inevitable in most tropical regions when dealing with arthropods. Many other published studies on spider diversity included specimen numbers similar to the total sampled at the MNR, ranging between 75 and 9375 individuals (see Coddington et al. 2009). This suggests that the data collected in the current study are not unacceptably incomplete.

Almost half the species recorded could not be identified beyond genus or even family level, which highlights a 
common problem with invertebrate surveys. In a survey of the Polokwane Nature Reserve by Dippenaar et al. (2008), a similar proportion (35\%) of unidentifiable spider species was found. Expertise for identification is usually limited to selected families and global experts may need to be consulted, which creates delays in obtaining data; in many cases even global expertise does not exist. The large number of unidentifiable specimens is also an indication of the incomplete knowledge of the fauna and the figures include the eight species recognised as new. It is possible that additional new species may be found amongst the material not identified to species level. Some of the species could not be identified because only immature specimens were collected, which is another common problem associated with invertebrate surveys.

Comparisons of recorded species richness across spider surveys of other biomes and areas are difficult because in some of the similar spider surveys sampling was not quantified and sampling effort may be unequal. However, Haddad and Dippenaar-Schoeman (2009) provided a range of between 76 and 431 species for South African conserved areas for which published surveys exist. None of the reserves they provided data for were in the forest or grassland biome. For the Polokwane Nature Reserve, 13821 specimens sampled over a year yielded 275 species (or a sample intensity of 50 specimens per species) (Dippenaar et al. 2008). In a heterogeneous area in India, Hore and Uniyal (2008) sampled 3666 individuals over a year, representing 160 species (a sample intensity of 23 specimens per species). At the MNR the sample intensity was approximately nine specimens per species. In spider surveys the ratio of individuals to species is initially low and increases as an increasing number of samples are taken and fewer new morphospecies are sampled (e.g. Cardoso et al. 2008). This indicates that the MNR survey (which provided a low specimens-to-species ratio) is only in the initial phase of discovery of biodiversity and supports the suggestion that much more sampling is needed to approach a complete inventory (high ratio value). Coddington et al. (2009) calculated sample intensities of less than 10 for some individual sampling methods, where they estimated the survey completeness to be around $60 \%$. The low sample intensity at the MNR could also indicate higher diversity than for areas where large numbers of specimens are required to record additional species.

Forests have been shown in many studies to have high species richness across many taxa, including spiders. This is often attributed to the higher structural complexity in forests (Hore \& Uniyal 2008). However, in India, Hore and Uniyal (2008) found that grassland also had high species richness and a diverse assemblage of spiders relative to forests. A similar pattern was evident at the MNR, with grassland sites showing high species richness. This would appear not to conform to the general trend of diversity being associated with obvious habitat heterogeneity (Yen 2009). Of course, the sampling methods used in the two biomes may not be directly comparable with regard to effort, but this aspect of spider diversity should be investigated further.

Hore and Uniyal (2008) found that annual burning of grassland did not seem to affect spider diversity negatively.
TABLE 2: Spider families sampled at the Mkambati Nature Reserve and diversity within each family, in order of decreasing species richness.

\begin{tabular}{|c|c|c|c|}
\hline Family & Genera & Species & Total \\
\hline Araneidae & 17 & 22 & 329 \\
\hline Theridiidae & 15 & 22 & 201 \\
\hline Thomisidae & 12 & 19 & 80 \\
\hline Salticidae & 14 & 18 & 224 \\
\hline Linyphiidae & 6 & 6 & 74 \\
\hline Philodromidae & 4 & 4 & 16 \\
\hline Sparassidae & 2 & 4 & 13 \\
\hline Clubionidae & 1 & 4 & 73 \\
\hline Dictynidae & 2 & 2 & 2 \\
\hline Pisauridae & 3 & 3 & 21 \\
\hline Uloboridae & 3 & 3 & 12 \\
\hline Scytodidae & 1 & 2 & 13 \\
\hline Lycosidae & 2 & 2 & 12 \\
\hline Mimetidae & 2 & 2 & 8 \\
\hline Corinnidae & 2 & 2 & 70 \\
\hline Miturgidae & 2 & 2 & 23 \\
\hline Tetragnathidae & 2 & 2 & 23 \\
\hline Cyatholipidae & 1 & 1 & 1 \\
\hline Cyrtaucheniidae & 1 & 1 & 1 \\
\hline Deinopidae & 1 & 1 & 6 \\
\hline Gnaphosidae & 1 & 1 & 1 \\
\hline Anapidae & 1 & 1 & 1 \\
\hline Oxyopidae & 1 & 1 & 1 \\
\hline Pholcidae & 2 & 2 & 39 \\
\hline Amaurobiidae & 1 & 1 & 1 \\
\hline Selenopidae & 1 & 1 & 11 \\
\hline Zodariidae & 1 & 1 & 3 \\
\hline Zoridae & 1 & 1 & 12 \\
\hline Zoropsidae & 1 & 1 & 4 \\
\hline Total & 103 & 132 & 1275 \\
\hline
\end{tabular}

Total indicates the total number of individuals sampled.

This was also seen at the MNR, where two of the frequently burnt grassland sites were amongst the 10 sites of highest species density. This could be explained by higher herbivore density in newly resprouted grass and thus higher prey density, but the diversity of spider species rather than simple abundance is interesting. However, this study did not specifically investigate the effects of burning on spider diversity and conclusions cannot be drawn for the small number of sites sampled.

The site with the highest species density was the largest forest site (F26, the 'Superbowl forest'). This might be explained by higher sampling effort exercised than for the other forests (tree beating was performed in 20 rather than 10 trees), but even so, this forest does house at least one new species that may be a narrow endemic, seven species that are near endemics for the Eastern Cape, and 26 species that were not identified to species level. Additional sampling will be required to validate this preliminary assessment of the sites, but the Superbowl forest appears to be a high priority for the spider fauna. The survey suggests that additional sampling of the spider fauna would be productive, especially in view of the threats to the region. Other aspects that require investigation are the comparison of the grassland and forest habitats with regard to their invertebrate fauna using comparative sampling methods and efforts, and further investigation of fire impacts in the grassland areas. 


\section{Conclusion}

Baseline data on spiders are provided for the first time for a conserved area in Pondoland, Eastern Cape. A total of 132 species, including at least eight new species, were recorded from the MNR. Grassland and forest sites had a similar average number of species and each had a distinct fauna, indicating that both biomes require conservation measures. A single site yielded $34 \%$ of the total number of species recorded, whilst only seven species (5\%) were sampled from more than $50 \%$ of the sites. Although the survey was not comprehensive, preliminary data suggest a high turnover of species even at the small scale at which the survey was carried out, which means that a large area is likely to be required to conserve the spider fauna. This finding should be considered in setting conservation targets for Pondoland grassland and forest. In addition, any loss of area in the MNR may result in the loss of species in the reserve because most areas have unique species. Of the eight new species recorded, five may be confined to the MNR or the Pondoland area. This means that these species would be at high risk of extinction without the conservation area, and 15 other species endemic to the Pondoland and KwaZulu-Natal region would have their risk of extinction increased if the MNR is not adequately conserved.

The results from this study provide a platform for much needed future spider research in Pondoland, Eastern Cape, and the species data can be used in future conservation and environmental impact assessments.

\section{Acknowledgements}

We thank the Earthwatch Institute for sponsoring the project and for field assistance by the volunteers. Eastern Cape Nature Conservation, through Dr Dave Balfour and $\mathrm{Mr}$ Jan Venter, also contributed to funding for the project and provided logistical support during fieldwork. Funding was also provided by the National Research Foundation through a grant to M.H. Various field and laboratory assistants (Jessica Cochrane, Lynne Stone and Patsy Birkett, in particular) and collaborator Rob Slotow of the University of KwaZuluNatal are thanked for their contributions to the project. The University of KwaZulu-Natal is thanked for providing access to a vehicle and laboratory facilities. Two anonymous reviewers are thanked for useful suggestions to improve the manuscript.

\section{Author's contributions}

A.S.D. identified most of the material and presented statistical data. M.H. was the project leader, supervised the fieldwork and sorting of material, drafted the manuscript and took habitat photographs. C.H. identified Corinnidae and Salticidae, designed the map, and prepared the manuscript for submission. A.S.D., M.H. and C.H. all contributed to writing the manuscript.

\section{References}

Balmford, A. \& Gaston, K.J., 1999, 'Why biodiversity surveys are good value', Nature 398, 204-205. http://dx.doi.org/10.1038/18339
Black, S.H., Shepard, M. \& Allen, M.M., 2001, 'Endangered invertebrates: The case for greater attention to invertebrate conservation', Endangered Species Update for greater $42-50$.

Branch, W.R., 2002, 'Terrestrial fauna', in N2 Wild Coast Toll Road between Durban and East London, environmental impact assessment report, CCA Environmental (Pty) Ltd, Cape Town.

Cardoso, P., Crespo, L.C., Carvalho, R., Rufino, A.C. \& Henriques, S.S., 2009, 'Ad-Hoc vs. standardized and optimized arthropod diversity sampling', Diversity 1, 36-51. vs. Standardized and optimized arthropos
http://dx.doi.org/10.3390/d1010036

Cardoso, P., Scharff, N., Gaspar, C., Henriques, S.S., Carvalho, R., Castro, P.H. et al., 2008 , 'Rapid biodiversity assessment of spiders (Araneae) using semi-quantitative sampling: A case study in a Mediterranean forest', Insect Conservation and Diversity 1, 71-84.

Coddington, J.A., Agnarsson, I., Miller, J.A., Kuntner, M. \& Hormiga, G., 2009 'Undersampling bias: The null hypothesis for singleton species in tropical
(n) 'Undersampling bias: The null hypothesis for singleton species in tropical

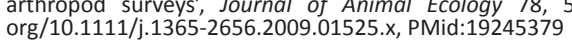

Dippenaar, S.M., Modiba, M.A., Khoza, T.T. \& Dippenaar-Schoeman, A.S., 2008, 'A checklist of the spiders (Arachnida, Araneae) of the Polokwane Nature Reserve, Limpopo Province, South Africa', Koedoe 50, 10-17.

Dippenaar-Schoeman, A.S., 2006, 'New records of 43 spider species from the Mountain Zebra National Park, South Africa (Arachnida: Araneae)', Koedoe 49, 23-28.

Dippenaar-Schoeman, A.S. \& Craemer, C., 2000, 'The South African National Survey of Arachnida', Plant Protection News 56, 11-12.

Dippenaar-Schoeman, A.S. \& Leroy, A., 2003, 'A check list of the spiders of the Kruger National Park, South Africa (Arachnida: Araneae)', Koedoe 46, 91-100.

Dippenaar-Schoeman, A.S., Leroy, A., De Jager, M. \& Van den Berg, A., 1999, 'A check list of the spider fauna of the Karoo National Park, South Africa (Arachnida: Araneae)', Koedoe 42, 31-42.

Dippenaar-Schoeman, A.S., Van den Berg, A. \& Prendini, L., 2009, 'Spiders and scorpions (Arachnida: Araneae, Scorpiones) of the Nylsvley Nature Reserve, South Africa', Koedoe 51, 1-9. http://dx.doi.org/10.4102/koedoe.v51i1.161

Dippenaar-Schoeman, A.S., Van der Walt, A.E., De Jager, M., Le Roux, E. \& Van den Berg, A., 2005, 'The spiders of the Swartberg Nature Reserve in South Africa (Arachnida: Araneae)', Koedoe 48, 77-86.

Farrington, K. \& Davies, K., 2004, “The gentle art of letting the other fellow have your own way': Viewpoints on a media narrative used to promote the proposed N2 toll road', Southern African Journal of Environmental Education 21, 166-173.

Foord, S.H., Mafadza, M.M., Dippenaar-Schoeman, A.S. \& Van Rensburg, B.J., 2008, 'Micro-scale heterogeneity of spiders (Arachnida: Araneae) in the Soutpansberg, South Africa: A comparative survey and inventory in representative habitats', African Zoology 43, 156-174. http://dx.doi.org/10.3377/1562-7020-43.2.156

Gruner, D.S., 2004, 'Attenuation of top-down and bottom-up forces in a complex terrestrial community', Ecology 85, 3010-3022. http://dx.doi.org/10.1890/040020

Haddad, C.R. \& Dippenaar-Schoeman, A.S., 2009, 'A checklist of the non-acarine arachnids (Chelicerata: Arachnida) of the De Hoop Nature Reserve, Western Cape Province, South Africa', Koedoe 51, 1-9. http://dx.doi.org/10.4102/koedoe. v51i1.149

Haddad, C.R., Dippenaar-Schoeman, A.S. \& Wesolowska, W., 2006, 'A checklist of the non-acarine arachnids (Chelicerata: Arachnida) of the Ndumo Game Reserve, Maputaland, South Africa', Koedoe 49, 1-22.

Hore, U. \& Uniyal, V.P., 2008, 'Diversity and composition of spider assemblages in five vegetation types of the Terai Conservation Area, India', Journal of Arachnology 36 , vegetation types of the Terai Conservation Area,
251-258. http://dx.doi.org/10.1636/CT07-53.1

Janzen, D.H., 1987, 'Insect diversity of a Costa Rican dry forest: Why keep it, and how?', Biological Journal of the Linnean Society 30, 343-356. http://dx.doi. org/10.1111/j.1095-8312.1987.tb00307.x

Kepe, T., 2001, 'Tourism, protected areas and development in South Africa: Views of visitors to Mkambati Nature Reserve', South African Journal of Wildlife Research 31, 155-159.

Lovell, S., Hamer, M., Slotow, R. \& Herbert, D., 2009, 'An assessment of the use of volunteers for terrestrial invertebrate biodiversity surveys', Biodiversity and Conservation 18, 3295-3307. http://dx.doi.org/10.1007/s10531-009-9642-2

Luck, G.W., Daily, G.C. \& Ehrlich, P.R., 2003, 'Population diversity and ecosystem services', Trends in Ecology and Evolution 18, 331-336. http://dx.doi.org/10.1016/ S0169-5347(03)00100-9

Millennium Ecosystem Assessment, 2005, Ecosystems and human well-being Biodiversity synthesis, World Resources Institute, Washington DC.

Muelelwa, M.I., Foord, S.H., Dippenaar-Schoeman, A.S. \& Stam, E.M., 2010, 'Towards a standardized and optimized protocol for rapid assessments: Spider species richness and assemblage composition in two savanna vegetation types', African Zoology 45(2), 273-290. http://dx.doi.org/10.3377/004.045.0206

Platnick, N.I., 2010, The world spider catalog, version 10.5, viewed 08 June 2010, from http://research amnh org/entomology/spiders/catalog/index.html (American Museum of Natural History).

Rohr, J.R., Mahan, C. \& Kim, K., 2007, 'Developing a monitoring program for invertebrates: Guidelines and a case study', Conservation Biology 21, 422-433. http://dx.doi.org/10.1111/j.1523-1739.2006.00578.x, PMid:17391192

Schmitz, O.J., 2003, 'Top predator control of plant biodiversity and productivity in an old-field ecosystem', Ecology Letters 6, 156-163. http://dx.doi.org/10.1046/ j.1461-0248.2003.00412.x

Van Wyk, A.E. \& Smith, G., 2001, Regions of floristic endemism in Southern Africa, Umdaus Press, Pretoria.

Ward, D.F. \& Larivière, M.C., 2004, 'Terrestrial invertebrate surveys and rapid biodiversity assessment in New Zealand: Lessons from Australia', New Zealand Journal of Ecology 28, 151-159.

Yen, J.D.L., 2009, 'Spider family richness and habitat complexity', Victorian Naturalist $126,18-22$ 


\section{Appendix}

APPENDIX: List of spider species sampled at the Mkambati Nature Reserve (January-February 2008).

\begin{tabular}{|c|c|c|c|c|c|c|c|c|c|c|}
\hline \multirow[t]{2}{*}{ Family } & \multirow[t]{2}{*}{ Genus/species } & \multirow[t]{2}{*}{ GU } & \multirow[t]{2}{*}{ DI } & \multicolumn{4}{|c|}{ Sampling method } & \multirow[t]{2}{*}{ Total } & \multirow[t]{2}{*}{ HB } & \multirow[t]{2}{*}{ Sites } \\
\hline & & & & SN & PT & TB & OM & & & \\
\hline Amaurobiidae & Chresiona sp. $1 \dagger$ & RWB & 5 & - & - & 1 & - & 1 & $\mathrm{~F}$ & 1 \\
\hline Anapidae & undetermined sp. 1 & OWB & $?$ & 1 & - & - & - & 1 & G & 1 \\
\hline \multirow[t]{21}{*}{ Araneidae } & Araniella sp. 1 & OWB & 3 & 1 & - & - & - & 1 & G & 1 \\
\hline & Araneus nigroquadratus Lawrence, 1937 & OWB & 2 & - & - & 1 & - & 1 & $\mathrm{~F}$ & 2 \\
\hline & Caerostris sexcuspidata (Fabricius, 1793) & OWB & 1 & - & - & 1 & - & 1 & $\mathrm{~F}$ & 1 \\
\hline & Cyclosa insulana (Costa, 1834) & OWB & 1 & - & - & 1 & - & 1 & $\mathrm{~F}$ & 1 \\
\hline & Cyclosa sp. 2 (immature) & OWB & $?$ & - & - & 1 & - & 1 & $\mathrm{~F}$ & 1 \\
\hline & Cyrtophora citricola (Forsskål, 1775) & OWB & 1 & - & - & 2 & - & 2 & $\mathrm{~F}$ & 1 \\
\hline & Cyrtophora sp. $2 \dagger$ & OWB & 4 & - & - & 5 & - & 5 & $\mathrm{~F}$ & 3 \\
\hline & Gea infuscata Tullgren, 1910 & OWB & 2 & 15 & 1 & - & - & 16 & G & 8 \\
\hline & Hypsosinga lithyphantoides Caporiacco, 1947 & OWB & 1 & 28 & - & - & - & 28 & G & 8 \\
\hline & Hypsosinga sp. $2 \dagger$ & OWB & 3 & 20 & - & - & - & 20 & G & 8 \\
\hline & Ideocaira transversa Simon, 1903 & OWB & 3 & 1 & - & 3 & - & 4 & $\mathrm{~F}$ & 3 \\
\hline & Kilima decens (Blackwall, 1866) & OWB & 1 & 6 & - & - & - & 6 & G & 4 \\
\hline & Lipocrea longissima (Simon, 1881) & OWB & 1 & - & - & 1 & - & 1 & $\mathrm{~F}$ & 1 \\
\hline & Neoscona blondeli (Simon, 1885) & OWB & 1 & 122 & 1 & 25 & 18 & 166 & $F / G$ & 20 \\
\hline & Neoscona moreli (Vinson, 1863) & OWB & 1 & 1 & - & - & 2 & 3 & G & 2 \\
\hline & Neoscona subfusca (C.L. Koch, 1837) & OWB & 1 & 19 & 2 & 1 & 3 & 25 & $F / G$ & 9 \\
\hline & Pararaneus cyrtoscapus (Pocock, 1898) & OWB & 1 & - & 5 & 1 & - & 6 & $\mathrm{~F} / \mathrm{G}$ & 6 \\
\hline & Poltys sp. $1 \dagger$ & OWB & 6 & - & - & 1 & - & 1 & $\mathrm{~F}$ & 1 \\
\hline & Pycnacantha tribulus (Fabricius, 1781) & OWB & 2 & 1 & - & - & - & 1 & G & 1 \\
\hline & Singa albodorsata Kauri, 1950 & OWB & 4 & 1 & - & - & - & 1 & G & 1 \\
\hline & undetermined sp. 1 & OWB & $?$ & 38 & - & - & - & 38 & G & 11 \\
\hline \multirow[t]{4}{*}{ Clubionidae } & Clubiona abbajensis Strand, 1906 & PWA & 1 & 1 & 2 & - & 6 & 9 & G & 4 \\
\hline & Clubiona pupillaris Lawrence, 1938 & PWA & 3 & 3 & 1 & 2 & 1 & 7 & $\mathrm{~F} / \mathrm{G}$ & 6 \\
\hline & Clubiona sp. 3 & PWA & $?$ & 27 & 7 & 12 & 7 & 53 & $F / G$ & 17 \\
\hline & Clubiona sp. 4 & PWA & $?$ & 1 & 3 & - & - & 4 & $F / G$ & 3 \\
\hline Cyatholipidae & Cyatholipus quadrimaculatus Simon, 1894 & SWB & 4 & 1 & - & - & - & 1 & G & 1 \\
\hline Cyrtaucheniidae & Homostola abernethyi (Purcell, 1903) & GWA & 5 & - & 1 & - & - & 1 & G & 1 \\
\hline Deinopidae & Menneus camelus Pocock, 1902 & OWB & 3 & 1 & - & 5 & - & 6 & $F / G$ & 5 \\
\hline \multirow[t]{2}{*}{ Dictynidae } & Dictyna sp. 1 & RWB & $?$ & 1 & - & - & - & 1 & G & 2 \\
\hline & Mashimo leleupi Lehtinen, 1967 & RWB & 1 & - & - & 1 & - & 1 & $\mathrm{~F}$ & 1 \\
\hline Gnaphosidae & Zelotes sp. 1 (immature) & GWA & $?$ & - & 1 & - & - & 1 & G & 1 \\
\hline \multirow[t]{6}{*}{ Linyphiidae } & Mecynidis dentipalpis Simon, 1894 & SWB & 4 & - & - & 5 & - & 5 & $\mathrm{~F}$ & 4 \\
\hline & Microlinphia sterilis (Pavesi, 1883) & SWB & 1 & - & - & 1 & - & 1 & $\mathrm{~F}$ & 1 \\
\hline & Typhistes sp. $1 \dagger$ & SWB & 6 & 1 & 3 & 22 & 1 & 27 & $F / G$ & 9 \\
\hline & undetermined sp. 1 & SWB & $?$ & 6 & 3 & - & - & 9 & G & 10 \\
\hline & undetermined sp. 2 & SWB & $?$ & 8 & 4 & - & - & 12 & G & 8 \\
\hline & undetermined sp. 3 & SWB & $?$ & 10 & 8 & 1 & 1 & 20 & $F / G$ & 11 \\
\hline \multirow[t]{2}{*}{ Lycosidae } & Hippasa australis Lawrence, 1927 & FWB & 1 & - & 9 & - & 1 & 10 & G & 2 \\
\hline & Pardosa sp. 1 (immature) & GWA & $?$ & 1 & 1 & - & - & 2 & G & 2 \\
\hline \multirow[t]{2}{*}{ Mimetidae } & Ero capensis Simon, 1895 & PWA & 4 & - & - & 7 & - & 7 & G & 3 \\
\hline & Mimetus natalensis Lawrence, 1938 & PWA & 3 & - & 1 & - & - & 1 & G & 1 \\
\hline \multirow[t]{2}{*}{ Miturgidae } & Cheiracanthium sp. 1 (immature) & PWA & $?$ & 8 & - & - & 9 & 17 & G & 12 \\
\hline & Cheiramiona sp. $1 \dagger$ & PWA & 6 & - & - & 6 & - & 6 & $\mathrm{~F}$ & 4 \\
\hline Oxyopidae & Oxyopes sp. 1 (immature) & PWA & $?$ & 1 & - & - & - & 1 & G & 1 \\
\hline Philodromidae & Philodromus sp. 1 (immature) & PWA & $?$ & 2 & - & - & - & 2 & G & 2 \\
\hline & Thanatus dorsilineatus Jezequel, 1964 & PWA & 1 & 8 & - & - & - & 8 & G & 5 \\
\hline & Tibellus seriepunctatus Simon, 1907 & PWA & 1 & 4 & - & - & - & 4 & G & 3 \\
\hline & Tibitanus sp. $1 \dagger$ & PWA & 6 & 1 & 1 & - & - & 2 & G & 2 \\
\hline
\end{tabular}

GU, guild (FWB, funnel web; GWA, ground wanderer; CWB, cob web; PWA, plant wanderer; RWB, retreat web; SWB, sheet web; SPWB, space web; OWB, orb web).

DI, distribution (6, endemic to reserve; 5 , endemic to the Eastern Cape; 4 , near endemic to the Eastern Cape (occurs in two provinces); 3 , endemic to South Africa; 2 , endemic to southern Africa; 1 , endemic to the Afrotropical Region; 0, cosmopolitan, occurs outside the Afrotropical Region; ?, data deficient).

Entries in sampling method columns (SN, sweep netting; PT, pan traps; TB, tree beating; OM, other methods) represent the number of individuals sampled by each method; Total, number of individuals sampled.

$H B$, habitat ( $G$, grassland only; $G / F$, grassland and forest; $F$, forest only).

Sites, number of sites at which each species was sampled.

$\dagger$, Possible new species. 
APPENDIX (Continues...): List of spider species sampled at the Mkambati Nature Reserve (January-February 2008).

\begin{tabular}{|c|c|c|c|c|c|c|c|c|c|c|}
\hline \multirow[t]{2}{*}{ Family } & \multirow[t]{2}{*}{ Genus/species } & \multirow[t]{2}{*}{ GU } & \multirow[t]{2}{*}{ DI } & \multicolumn{4}{|c|}{ Sampling method } & \multirow[t]{2}{*}{ Total } & \multirow[t]{2}{*}{ HB } & \multirow[t]{2}{*}{ Sites } \\
\hline & & & & SN & PT & TB & OM & & & \\
\hline \multirow[t]{2}{*}{ Pholcidae } & Smeringopus sp. 1 (immature) & SPWB & ? & - & - & 1 & - & 1 & $\mathrm{~F}$ & 1 \\
\hline & Spermophora sp. 1 & SPWB & $?$ & 1 & - & 37 & - & 38 & $\mathrm{~F}$ & 5 \\
\hline \multirow[t]{3}{*}{ Pisauridae } & Afropisaura rothiformis (Strand, 1908) & PWA & 1 & 17 & - & 1 & - & 18 & $F / G$ & 8 \\
\hline & Euprosthenopsis vuattouxi Blandin, 1977 & SWB & 1 & - & 1 & - & - & 1 & G & 1 \\
\hline & Maypacius bilineatus (Pavesi, 1895) & SWB & 1 & 1 & 1 & - & - & 2 & G & 2 \\
\hline \multirow[t]{17}{*}{ Salticidae } & Asemonea stella Wanless, 1980 & PWA & 1 & 2 & - & - & - & 2 & $F / G$ & 2 \\
\hline & Evarcha dotata (Peckham \& Peckham, 1903) & GWA & 1 & 2 & 13 & - & 1 & 16 & G & 10 \\
\hline & Heliophanus proszynskii Wesolowska, 2003 & PWA & 3 & 85 & 6 & 1 & 7 & 99 & $F / G$ & 16 \\
\hline & Heliophanus sp. 2 & PWA & ? & 13 & - & - & - & 13 & G & 7 \\
\hline & Icius sp. 1 & PWA & $?$ & 8 & - & - & - & 8 & G & 5 \\
\hline & Klamantia flava Peckham \& Peckham, 1903 & PWA & 4 & - & - & 5 & - & 5 & $\mathrm{~F}$ & 4 \\
\hline & Langaelurillus sp. 1 & GWA & $?$ & 1 & 4 & - & - & 5 & G & 4 \\
\hline & Myrmarachne foreli Lessert, 1925 & PWA & 1 & 2 & - & - & 2 & 4 & G & 2 \\
\hline & Nigorella hirsuta Wesołowska, 2009 & PWA & 2 & - & 1 & - & - & 1 & G & 1 \\
\hline & Pellenes sp. 1 (immature) & GWA & ? & 1 & - & - & - & 1 & G & 3 \\
\hline & Phintella aequipes (Peckham \& Peckham, 1903) & PWA & 1 & - & - & 2 & - & 2 & $\mathrm{~F}$ & 2 \\
\hline & Phlegra sp. 1 & PWA & $?$ & - & 9 & 2 & - & 11 & $F / G$ & 7 \\
\hline & Saitis leighi Peckham \& Peckham, 1903 & PWA & 4 & - & 1 & - & - & 1 & G & 1 \\
\hline & Thyene aperta (Peckham \& Peckham, 1903) & PWA & 1 & 2 & - & - & - & 2 & G & 2 \\
\hline & Thyene semiargentata (Simon, 1884) & PWA & 1 & 15 & 2 & 7 & 1 & 25 & $F / G$ & 13 \\
\hline & Thyenula aurantiaca (Simon, 1902) & PWA & 2 & - & - & 13 & 2 & 15 & $\mathrm{~F} / \mathrm{G}$ & 5 \\
\hline & Thyenula sp. 2 & GWA & ? & 1 & 5 & 2 & - & 8 & $F / G$ & 8 \\
\hline \multirow[t]{2}{*}{ Scytodidae } & Scytodes caffra Purcell, 1904 & GWA & 1 & - & 1 & 1 & - & 2 & $F / G$ & 2 \\
\hline & Scytodes constellata Lawrence, 1938 & PWA & 3 & - & 4 & 7 & - & 11 & $F / G$ & 6 \\
\hline Selenopidae & Anyphops purcelli (Lawrence, 1940) & PWA & 3 & - & 1 & 7 & 3 & 11 & $F / G$ & 6 \\
\hline \multirow[t]{2}{*}{ Sparassidae } & Olios biarmatus Lessert, 1925 & PWA & 4 & - & - & - & 1 & 1 & $\mathrm{~F}$ & 1 \\
\hline & Olios correvoni Lessert, 1921 & PWA & 2 & - & - & - & 3 & 3 & G & 3 \\
\hline \multirow[t]{2}{*}{ Tetragnathidae } & Leucauge festiva (Blackwall, 1866) & OWB & 1 & 8 & - & 1 & - & 9 & $F / G$ & 6 \\
\hline & Tetragnatha boydi O.P.-Cambridge, 1898 & OWB & 1 & 6 & - & 8 & - & 14 & $\mathrm{~F} / \mathrm{G}$ & 8 \\
\hline \multirow[t]{22}{*}{ Theridiidae } & Achaearanea sp. 1 & CWB & $?$ & - & - & 7 & - & 7 & $\mathrm{~F}$ & 4 \\
\hline & Anelosimus nelsoni Agnarsson, 2006 & CWB & 4 & - & - & 2 & - & 2 & $\mathrm{~F}$ & 1 \\
\hline & Argyrodes convivans Lawrence, 1937 & CWB & 3 & - & - & 1 & - & 1 & $\mathrm{~F}$ & 1 \\
\hline & Dipoena sp. 1 & CWB & $?$ & 2 & - & 7 & - & 9 & $F / G$ & 6 \\
\hline & Dipoenura sp. 1 & CWB & $?$ & 1 & - & 35 & - & 36 & $F / G$ & 6 \\
\hline & Enoplognatha sp. 1 & CWB & $?$ & - & 1 & - & - & 1 & G & 1 \\
\hline & Euryopis funebris (Hentz, 1850) & CWB & 0 & - & - & 7 & - & 7 & $\mathrm{~F}$ & 4 \\
\hline & Euryopis sp. 2 & CWB & $?$ & 5 & 1 & - & 3 & 9 & G & 8 \\
\hline & Euryopis sp. 3 & CWB & $?$ & 4 & 2 & 3 & 1 & 10 & $F / G$ & 6 \\
\hline & Latrodectus geometricus C.L. Koch, 1841 & CWB & 0 & 1 & - & - & - & 1 & G & 1 \\
\hline & Phoroncidia eburnea (Simon, 1895) & CWB & 3 & 4 & - & - & - & 4 & G & 2 \\
\hline & Steatoda capensis Hann, 1990 & CWB & 0 & - & 1 & - & - & 1 & G & 1 \\
\hline & Theridion piliphilum Strand, 1907 & CWB & 4 & - & - & 2 & - & 2 & $\mathrm{~F}$ & 1 \\
\hline & Theridion sp. 2 & CWB & $?$ & 14 & 2 & 22 & - & 38 & $F / G$ & 17 \\
\hline & Theridion sp. 3 & CWB & $?$ & 2 & 3 & 11 & - & 16 & $F / G$ & 6 \\
\hline & Theridion sp. 4 & CWB & $?$ & 18 & 3 & 11 & 2 & 34 & $F / G$ & 15 \\
\hline & Theridion sp. 5 & CWB & $?$ & 8 & - & 2 & - & 10 & $F / G$ & 7 \\
\hline & Theridion sp. 6 & CWB & $?$ & 3 & - & 2 & - & 5 & $\mathrm{~F}$ & 1 \\
\hline & Tidarren sp. 1 (immature) & CWB & $?$ & 1 & - & - & - & 1 & G & 1 \\
\hline & undetermined sp. 1 & CWB & $?$ & 2 & - & 2 & - & 4 & $\mathrm{~F}$ & 1 \\
\hline & undetermined sp. 2 & CWB & $?$ & 2 & - & - & - & 2 & G & 2 \\
\hline & undetermined sp. 3 & CWB & $?$ & 1 & - & - & - & 1 & G & 1 \\
\hline
\end{tabular}

GU, guild (FWB, funnel web; GWA, ground wanderer; CWB, cob web; PWA, plant wanderer; RWB, retreat web; SWB, sheet web; SPWB, space web; OWB, orb web).

$\mathrm{DI}$, distribution (6, endemic to reserve; 5 , endemic to the Eastern Cape; 4, near endemic to the Eastern Cape (occurs in two provinces); 3 , endemic to South Africa; 2 , endemic to southern Africa; 1, endemic to the Afrotropical Region; 0, cosmopolitan, occurs outside the Afrotropical Region; ?, data deficient).

Entries in sampling method columns (SN, sweep netting; PT, pan traps; TB, tree beating; OM, other methods) represent the number of individuals sampled by each method; Total, number of individuals sampled.

$H B$, habitat (G, grassland only; $G / F$, grassland and forest; $F$, forest only).

Sites, number of sites at which each species was sampled.

$\dagger$, Possible new species. 
APPENDIX (Continues...): List of spider species sampled at the Mkambati Nature Reserve (January-February 2008).

\begin{tabular}{|c|c|c|c|c|c|c|c|c|c|c|}
\hline \multirow[t]{2}{*}{ Family } & \multirow[t]{2}{*}{ Genus/species } & \multirow[t]{2}{*}{ GU } & \multirow[t]{2}{*}{ DI } & \multicolumn{4}{|c|}{ Sampling method } & \multirow[t]{2}{*}{ Total } & \multirow[t]{2}{*}{ HB } & \multirow[t]{2}{*}{ Sites } \\
\hline & & & & SN & PT & TB & OM & & & \\
\hline \multirow[t]{18}{*}{ Thomisidae } & Ansiae tuckeri (Lessert, 1919) & PWA & 1 & 1 & - & 1 & - & 2 & $F / G$ & 2 \\
\hline & Avelis hystriculus Simon, 1895 & PWA & 4 & - & - & 3 & - & 3 & $\mathrm{~F}$ & 3 \\
\hline & Borboropactus silvicola (Lawrence, 1938) & PWA & 4 & - & - & 1 & - & 1 & $\mathrm{~F}$ & 1 \\
\hline & Monaeses austrinus Simon, 1910 & PWA & 1 & 13 & - & - & - & 13 & G & 7 \\
\hline & Monaeses pustulosus Pavesi, 1895 & PWA & 1 & 3 & - & - & - & 3 & G & 3 \\
\hline & Monaeses sp. $3 \dagger$ & PWA & 6 & 6 & - & - & - & 6 & G & 4 \\
\hline & Oxytate concolor (Caporiacco, 1947) & PWA & 1 & - & - & - & 1 & 1 & $\mathrm{~F}$ & 1 \\
\hline & Pactates trimaculatus Simon, 1895 & PWA & 1 & 1 & - & - & - & 1 & G & 2 \\
\hline & Paramystaria variabilis Lessert, 1919 & PWA & 1 & - & - & - & 1 & 1 & $\mathrm{~F}$ & 1 \\
\hline & Runcinia flavida (Simon, 1881) & PWA & 1 & - & - & - & 1 & 1 & G & 1 \\
\hline & Runcinia grammica (L. Koch, 1937) & PWA & 1 & 8 & - & - & - & 8 & G & 3 \\
\hline & Synema imitator (Pavesi, 1883) & PWA & 1 & 3 & - & - & - & 3 & G & 2 \\
\hline & Thomisops sulcatus Simon, 1895 & PWA & 1 & 2 & - & - & - & 2 & G & 2 \\
\hline & Thomisus dalmasi Lessert, 1919 & PWA & 1 & - & - & - & 1 & 1 & $\mathrm{~F}$ & 1 \\
\hline & Thomisus granulatus Karsch, 1880 & PWA & 2 & 1 & - & - & - & 1 & G & 1 \\
\hline & Thomisus scrupeus (Simon, 1886) & PWA & 1 & 4 & - & 2 & - & 6 & $F / G$ & 3 \\
\hline & Thomisus stenningi Pocock, 1900 & PWA & 1 & 3 & - & - & 2 & 5 & G & 4 \\
\hline & Tmarus comellinii Garcia-Neto, 1989 & PWA & 1 & - & - & 7 & - & 7 & $\mathrm{~F}$ & 4 \\
\hline \multirow[t]{3}{*}{ Uloboridae } & Hyptiotes akermani Wiehle, 1964 & OWB & 3 & - & - & 1 & - & 1 & $\mathrm{~F}$ & 1 \\
\hline & Miagrammopes brevicaudus O.P.-Cambridge, 1882 & OWB & 3 & - & - & 4 & - & 4 & $\mathrm{~F}$ & 1 \\
\hline & Uloborus planipedius Simon, 1896 & OWB & 1 & - & 1 & 6 & - & 7 & $F / G$ & 4 \\
\hline Zodariidae & Chariobas lineatus Pocock, 1900 & PWA & 4 & 3 & - & - & - & 3 & G & 1 \\
\hline Zoridae & Voraptus affinis Lessert, 1925 & GWA & 3 & 2 & 10 & - & - & 12 & G & 7 \\
\hline Zoropsidae & Griswoldia transversa (Griswold, 1991) & GWA & 4 & - & 4 & - & - & 4 & G & 3 \\
\hline Total & - & - & - & 635 & 206 & 342 & 92 & 1275 & - & - \\
\hline
\end{tabular}

GU, guild (FWB, funnel web; GWA, ground wanderer; CWB, cob web; PWA, plant wanderer; RWB, retreat web; SWB, sheet web; SPWB, space web; OWB, orb web).

$\mathrm{DI}$, distribution (6, endemic to reserve; 5, endemic to the Eastern Cape; 4, near endemic to the Eastern Cape (occurs in two provinces); 3, endemic to South Africa; 2, endemic to southern Africa; 1, endemic to the Afrotropical Region; 0, cosmopolitan, occurs outside the Afrotropical Region; ?, data deficient).

Entries in sampling method columns (SN, sweep netting; PT, pan traps; TB, tree beating; OM, other methods) represent the number of individuals sampled by each method; Total, number of individuals sampled.

$H B$, habitat (G, grassland only; $G / F$, grassland and forest; F, forest only).

Sites, number of sites at which each species was sampled.

$\dagger$, Possible new species. 